\title{
Evaluation of Heavy Metals Uptakes of Lettuce (Lactuca sativa L.) Under Irrigation Water of Akaki River, Central Ethiopia
}

\author{
Dagne Bekele Bahiru \\ Ethiopian Institute of Agricultural Research, Debre Zeit Agricultural Research Center, Department of Natural Resource Management, Debre \\ Zeit, Ethiopia
}

Email address:

ddagnebbk19@gmail.com

To cite this article:

Dagne Bekele Bahiru. Evaluation of Heavy Metals Uptakes of Lettuce (Lactuca sativa L.) Under Irrigation Water of Akaki River, Central Ethiopia. American Journal of Environmental Science and Engineering. Vol. 5, No. 1, 2021, pp. 6-14. doi: 10.11648/j.ajese.20210501.12

Received: February 9, 2021; Accepted: March 24, 2021; Published: April 20, 2021

\begin{abstract}
The present study was implemented to remediate heavy metal levels in lettuce grown by Akaki river water in 45 pots. The soil for the pot experiment collected from the Akaki area and the water used for lettuce growing from the upper, middle, and lower part of Akaki River with five treatment for three locations: groundwater (control), 25, 50, 75, and 100\% Akaki river water with groundwater combination set as treatment. The results obtained from this pot experiment in lettuce samples $\mathrm{Cd}, \mathrm{Pb}, \mathrm{Fe}, \mathrm{Zn}, \mathrm{Cr}$, and $\mathrm{Cu}$ concentration in the range of (0.047-0.263), (0.42-6.55), (339.83-420.00), (2.96-13.44), (0.95-7.87) and (1.68-7.49) $(\mathrm{mg} / \mathrm{Kg})$ respectively, all heavy metal concentration except groundwater irrigated lettuce sample above-recommended level set by WHO (1999). Whereas, Concentration of these metals in the soil samples (mg/ $\mathrm{kg}$ ) was found to be $\mathrm{Cd}$ (0.47-3.47), $\mathrm{Pb}$ (8.00-118.00), Fe (13557.30-16800.00), Zn (40.00-224.67), $\mathrm{Cr}$ (4.91-39.36) and $\mathrm{Cu}(35.00-149.88)$, out of $\mathrm{Cd}$ and $\mathrm{Fe}$ heavy metal concentration in Akaki river water irrigated soil samples except $100 \%$ Akaki river water irrigated soil sample was below the recommended level set by /FAOWHO (2001). Similarly, concentrations $(\mathrm{mg} / \mathrm{L})$ of the metals in the Akaki river water samples were found to be in the ranges of 0.18-0.28, 1.40-2.67, 0.97-1.40, 0.037-0.087, 0.037-0.080, and 010.14 for $\mathrm{Fe}, \mathrm{Zn}, \mathrm{Cu}, \mathrm{Cd}, \mathrm{Pb}$, and $\mathrm{Cr}$, respectively. The concentrations of heavy metals in the Akaki river water and lettuce samples were above the recommended limit of both WHO and FAO. Also, Cd and Fe for the soil samples were greater than WHO and FAO recommended limit. Based on facts obtained from this study we suggest concerned official body (ies) take the necessary precaution measures for cleaning the Akaki river water.
\end{abstract}

Keywords: Heavy Metals, Lettuce, Akaki River Water

\section{Introduction}

Heavy metals (HM) are extremely persistent in the environs. HMs are non-biodegradable and non-thermo degradable and they are readily accumulate to toxic levels in environment [1].

Wastewater and likely to increase markedly during the next few decades as water stress intensifies [2-4]. The aim of wastewater irrigation are that it delivers a consistent source of irrigation water for farmers and it has the helpful aspects of adding valuable plant nutrients and organic matter to soil [5], which are creating both opportunities and problems for the farming sector $[6,7]$. Plants have a natural tendency to take up metals. Some of them like $\mathrm{Cu}^{2+}, \mathrm{Co}^{2+}, \mathrm{Fe}^{2+}, \mathrm{Mo}^{2+}$,
$\mathrm{Mn}^{2+}$, and $\mathrm{Zn}^{2+}$ are essential plant micronutrients [8], while few others like $\mathrm{Hg}^{2+}, \mathrm{Cd}^{2+}, \mathrm{Ni}^{2+}$ and $\mathrm{Pb}^{2+}$ are toxic to plants. Conversely, those like toxic HMs harmfulness effect are vary from genotype to genotype of the same crop [5]. Leafy vegetables are highly metal accumulator with compare to root vegetables and legumes [9].

Vegetables found in Akaki area are lettuce; spinach, carrots, radish, cabbage, potato, tomato, etc. are frequently grown in Peri-urban areas of Akaki and irrigated by the city effluents (Akaki river water). The direct use of untreated wastewater is common in developing countries, which are due to the lack of alternative water sources, The use of city effluents for irrigation purpose may also result in accumulation of macro $\left(\mathrm{Na}^{+}, \mathrm{K}^{+}, \mathrm{Mg}^{2+}, \mathrm{Ca}^{2+}\right)$ and micro-essential elements $\left(\mathrm{Fe}^{2+}\right.$, 
$\left.\mathrm{Mn}^{2+}, \mathrm{Zn}^{2+}\right)$ as well as trace and toxic elements $\left(\mathrm{Pb}^{2+}, \mathrm{Ni}^{2+}\right.$, $\mathrm{Cd}^{2+}, \mathrm{Cr}^{2+}$, and $\mathrm{Co}^{2+}$ ) in phytotoxic concentrations [10], which may adversely affect the human metabolism. Therefore, wastewater application on agricultural lands and their heavy metal accumulation by vegetables is a cause of serious concern due to the potential public health impacts. It is often argued that heavy metals such as $\mathrm{Cd}^{2+}, \mathrm{Ni}^{2+}$ or $\mathrm{Pb}^{2+}$ in sludge, when applied to soils, may enter in the food chain through plants or animals, contaminate surface and groundwater, and thus cause health hazards [11, 12]. This study was therefore; mainly focused to formulation suitable delusion of contaminated Akaki river water with irrigation or groundwater for the production of lettuce.

\section{Materials and Methods}

\subsection{Study Area}

Akaki river catchment is found in central Ethiopia sideway of the western border of the main Ethiopian Rift Valley. The river catchment is found $8^{\circ} 46^{\prime}-9^{\circ} 14^{\prime} \mathrm{N}$ and $38^{\circ} 34^{\prime}-39^{\circ} 04^{\prime} \mathrm{E}$, and the of river catchment are $1500 \mathrm{~km}^{2}$ [13]. Addis Ababa, which lies within the Akaki catchment, has a fast population growth, abandoned development and industrialization, poor sanitation, untreated waste dumping, which results in a serious deterioration of surface and groundwater quality. As it is the country's commercial, manufacturing and cultural center, large quantities of solid, liquid and gaseous wastes are generated and released into the environment of the city, most often untreated [14]. Aba Samuel reservoir was assembled in 1939 at the middle part of Akaki River. It was the first hydropower station in Ethiopia, but it was abandoned in 1970s, because of many years of lack of maintenance, siltation and pollution issues [15]. It was rebuilt and revived in 2016. The local people in the Akaki River catchment and Aba Samuel reservoir use the water for irrigation, drinking water for cattle, washing clothes, waste disposal site and other domestic needs without information on the level of water quality parameters [16]. Therefore, this study has been conducted in some parts of Upper (Akaki sub city), middle (Aba Samuel reservoir) and lower (Abo sera area before joining of Awash River).

\subsection{Soil Collection}

Soil sample were collected from0-20 cm depth with an auger from Alkali district for laboratory analysis and pot experiment around the Akaki river that are $2 \mathrm{~km}$ away from irrigation farm in the area, the soil was possibly non contaminated with heavy metals [17]. Then the samples were transported to the DZARC soil lab for lab analysis and pot experiment. Larger soil particles and debris were eliminated from the soil samples and then samples were air dried at room temperature $\left(2^{\circ} \mathrm{C}\right)$ for 7 days. Then the sample separated in to pot experiment and lab analysis. The sample for lab analysis were milled with a mortar and pestle to pass through a $2 \mathrm{~mm}$ sieve and homogenized. The prepared samples were placed in polyethylene bags until the time of analysis.

\subsection{Akaki River water Sampling}

The water was collected from three stations of Akaki River namely: upper, middle and lower part of the river. Samples were collected for three months from December, 2018 to February, 2019 at ten days interval for pot experiment irrigation water. The water samples were collected from 0.5 meter below the water surface and collected in clean and dry polyethylene bottles. For heavy metal analysis from upper, middle and lower part of the river water samples were collected and immediately acidified by $1 \mathrm{ml}$ nitric acid, for the purpose of keeping metals in the samples and avoid the adsorption container walls [18].

\subsection{Experimental Setup}

For the determination levels of HMs in lettuce it was irrigated with five different combination of wastewater (treatments) collected from 3 different point of the Akaki River (upper, middle and lower part of the river). The treatments $(\mathrm{T})$ were be made by dissolving calculated amount of wastewater (Akaki river water (WW)) in irrigation water (ground water IW)) in the Debre Zeit Agricultural Research Center i.e., control, 25, 50, 75, and 100\%. Those treatments were then designated by this abbreviation IW, 75\%IW+WW, $50 \% \mathrm{IW}+\mathrm{WW}, 25 \% \mathrm{IW}+\mathrm{WW}$ and $\mathrm{WW}$ respectively. Each treatment were replicated 3 times. Lettuce grown in 45 pots contained well-mixed possibly non-contaminated garden soil collected from Akaki area. They were then arranged in proper distance to avoid any possible external contamination along with the provision of possible uniform light condition. 4 healthy and uniform seeds of lettuce were sown at onecentimeter depth at an equal distance. Pots were arranged in a completely randomized design (CRD) in green house, and were then equally irrigated with respective treatments of wastewater and irrigation water. All standard agricultural practices were made during the course of germination, growth and development. Before initiation of flowers, plant samples were made by taking three leaves each from all treatments and replicates. Each treated plant sample was washed separately with $1 \%$ of $\mathrm{HCl}$. They will be then followed by 3-4 washings with de-ionized water to remove the foreign materials. These samples were then spread on blotting paper and air-dried, then oven dried at $70^{\circ} \mathrm{C}$. Then the samples for lab analysis were ground with a mortar and pestle and homogenized samples were placed in polyethylene bags until the time of analysis [17]. And the soil sample from each pot were collected and follow the proper preparation method for laboratory analysis.

\subsection{Digestion of Soil, Water and Lettuce Samples}

\subsubsection{Water Samples Digestion}

A $50 \mathrm{~mL}$ filtered aliquot of water sample was pipetted into a digestion flask. The metal percentage found in the water was determined by digestion in $3 \mathrm{~mL}$ concentrated $\mathrm{HNO}_{3}$ and $3 \mathrm{~mL}$ $\mathrm{H}_{2} \mathrm{O}_{2}$ below $80^{\circ} \mathrm{C}$ for $1 \mathrm{~h}$ until a clear solution was observed. 
The clear solution was diluted to $100 \mathrm{~mL}$ volumetric flask with distilled water and blank digestion was also carried out in the same way [19]. All samples were digested in triplicates. For heavy metal analysis FAAS was used.

\subsubsection{Lettuce Samples Digestion}

A $0.5 \mathrm{~g}$ powdered lettuce sample, $10 \mathrm{~mL} \mathrm{HNO}_{3}-\mathrm{HCl}-\mathrm{H}_{2} \mathrm{O}_{2}$ $(8: 1: 1, \mathrm{v} / \mathrm{v} / \mathrm{v})$ were added in a borosilicate digestion flask. The mixture were heated at $120^{\circ} \mathrm{C}$ over $3 \mathrm{~h}$ on block digester. After digestion completed, the clear and colorless solution were filtered into $50 \mathrm{~mL}$ volumetric flask. Each digestion tube were rinsed with distilled water to collect any possible residue, and added to the volumetric flask which made up to volume with distilled water. Then dilute samples were stored in $100 \mathrm{~mL}$ plastic bottles (high density polyethylene) until analysis. The blank solution was prepared by taking a mixture of $8 \mathrm{~mL} \mathrm{HNO}_{3}, 1 \mathrm{~mL} \mathrm{HCl}$ and $1 \mathrm{~mL} \mathrm{H}_{2} \mathrm{O}_{2}$ and treating similarly as that of the sample $[17,20]$.

\subsubsection{Soil Samples Digestion}

The $0.5 \mathrm{~g}$ dried and homogenized soil samples were transferred in to $100 \mathrm{~mL}$ digestion flask. In each of these flasks, $5 \mathrm{~mL}$ of deionized water and $30 \mathrm{~mL}$ of a mixture $\mathrm{HNO}_{3}(69 \%)$ and $37 \% \mathrm{HCl}$ with volume ratio of $5: 1$ were added. The sample dissolved in the acid mixture was digested in digestion hood (at $200^{\circ} \mathrm{C}$ ) for $1 \mathrm{~h}$ and kept to cool. After adding $2 \mathrm{~mL}$ of $\mathrm{H}_{2} \mathrm{O}_{2}$ to the cold digestion mixture, the final, the mixture was filtered out through filter paper to a $100 \mathrm{~mL}$ volumetric flask and diluted to the mark with deionized water [21]. Heavy metal content determination was done by FAAS. The blank reagent was also digested following the same procedure as the soil sample.

\subsection{Soil Physicochemical Property Analysis}

Selected Soil physicochemical property were conducted on experimental soil before sowing and after harvesting, following standard soil analytical procedures according to their parameters.

The $\mathrm{pH}$ was measured potentiometrically in the supernatant suspension of $1: 2.5$ soils to liquid ratio using distilled water $(\mathrm{pH}-\mathrm{H} 2 \mathrm{O}),[22]$. Electrical conductivity (EC) was measured using digital conductometer from the supernatant used for determination of $\mathrm{pH}-\mathrm{H} 2 \mathrm{O}$ [23]. Organic carbon $(\mathrm{OM})$ was determined by Walkley-Black wet oxidation method of the organic matter with potassium dichromate in the presence of sulphuric acid. The residual dichromate was titrated against ferrous sulphate to determine the amount of dichromate consumed by organic carbon or organic matter [24]. Total nitrogen (TN) was determined by Kjeldahl method using sulfuric acid and mixed catalyst to convert organic nitrogenous to ammonium sulfate. The distillation process was conducted in the presence of $10 \%$ sodium hydroxide to evolve ammonium in the form of ammonia gas [25]. Soil P content was determined before sowing and after harvesting, using Olsen method [26]. The extracts were determined spectrophotometrically with blue ammonium molybdate method in the presence of ascorbic acid which is used as reducing agent. Cation exchangeable capacity (CEC) was determined, from extracts which were obtained from residue of exchangeable cations, after removal of unbounded ammonium salt with $97 \%$ alcohol and then extracted with $10 \% \mathrm{NaCl}$. The distillation was conducted using Kjeldahl distillation apparatus and the quantification made by titration method, [27].

\subsection{Statistical Analysis and Data Interpretation}

All the data generated from the pot experiments were subjected to statistical analysis using (SAS 9.0). Significant difference among treatment means was assessed using the least significant difference (LSD) test at 0.05 probability level [28].

\section{Result and Discussion}

\subsection{Physico-Chemical Analysis of Soil Samples}

The mean concentrations of $\mathrm{pH}$, electrical conductivity (EC), total nitrogen, organic matter, and available phosphorus Cation exchangeable capacity before sowing were 7.89, 0.17 $\mathrm{dm} / \mathrm{S}, 0.12 \%, 2.37 \%, 8.50 \mathrm{mg} / \mathrm{kg}$ and $24.23 \mathrm{cmol} / \mathrm{kg}$, respectively and after harvesting of lettuce from pot experiment were also the above listed parameter were determined and presented in Table 1 . The $\mathrm{pH}$ values of the soil samples range from $7.77-8.22$ are moderately alkaline. Consequently, it shows that alkaline ranges of soils are known to limit the mobilization of HMs and thus reduce the uptake of heavy metals by plants [29]. In general, most of HMs are less available to plants under alkaline conditions than under acid conditions.

The electrical conductivity values of the soil samples range from $0.11-0.17 \mathrm{dS} / \mathrm{m}$. Conductivity is a degree of the ability of aqueous solution to carry an electric current that depends on the presence and total concentrations of ions, their mobility and valance and on the temperature [30].

The Available $\mathrm{P}$ values of the soil samples before sowing and after harvesting range from $8.17-12.42 \mathrm{mg} / \mathrm{kg}$ in medium range before sowing and after harvesting the pot experiment [31]. The nitrogen content of the soil before sowing and after harvesting was found to be low as rated by London [32].

Organic matter accumulates at the soil surface, mainly as a result of decomposing plant material. Whilst the organic matter content of soils is often small compared to that of clay, the organic fraction has a significant influence on metal binding. The mechanisms involved in the retention of metals by organic matter appear to include both complexation and adsorption, i.e. inner sphere reactions may take place as well as ion exchange [33]. Increase in soil organic matter content leads to elevation of soil adsorption capacity hence enhancing the accumulation of trace metals. Organic matters can therefore, be considered as an important medium through which heavy metals are incorporated into the soil [34].

The CEC is an important parameter of soil because it gives an indication of the type of the dominant clay minerals 
present in the soil and its capacity to retain nutrients against leaching. The CEC is strongly affected by the nature and amount of mineral and organic colloids present in soil. Soils with large amount of clay and organic matter have higher CEC than sandy soil low in organic matter.

Table 1. Soil physicochemical properties after harvesting of lettuce.

\begin{tabular}{|c|c|c|c|c|c|c|c|}
\hline & Parameter & $\% \mathrm{TN}$ & $\% O \mathrm{OM}$ & P mg/kg & $\mathrm{EC} \mathrm{dS/m}$ & PH & CEC cmol/kg \\
\hline & IW & $0.097 d$ & $1.69 \mathrm{~b}$ & $8.17 \mathrm{c}$ & $0.12 \mathrm{c}$ & 8.04ab & $27.34 \mathrm{bc}$ \\
\hline \multirow{7}{*}{ upper water } & $75 \% \mathrm{IW}+\mathrm{WW}$ & $0.103 \mathrm{~cd}$ & $1.83 \mathrm{ab}$ & $9.70 \mathrm{~b}$ & $0.13 \mathrm{c}$ & $8.18 \mathrm{a}$ & $27.25 c$ \\
\hline & $50 \% \mathrm{IW}+\mathrm{WW}$ & $0.117 b c$ & $1.93 \mathrm{ab}$ & $10.07 b$ & $0.14 b$ & $8.05 \mathrm{ab}$ & $32.03 \mathrm{ab}$ \\
\hline & $25 \% \mathrm{IW}+\mathrm{WW}$ & $0.123 \mathrm{ab}$ & $1.94 \mathrm{ab}$ & $10.20 b$ & $0.15 b$ & $7.95 b$ & $33.41 \mathrm{a}$ \\
\hline & WW & $0.137 \mathrm{a}$ & $2.13 \mathrm{a}$ & $12.17 \mathrm{a}$ & $0.17 \mathrm{a}$ & $7.90 \mathrm{~b}$ & $32.67 \mathrm{a}$ \\
\hline & $\mathrm{CV}$ & 6.716 & 10.46 & 9.59 & 4.30 & 1.28 & 8.29 \\
\hline & $\operatorname{LSD}(0.05)$ & 0.015 & 0.38 & 1.27 & 0.01 & 0.19 & 4.77 \\
\hline & $75 \% \mathrm{IW}+\mathrm{WW}$ & $0.087 b c$ & $1.87 \mathrm{~b}$ & $8.95 b$ & $0.12 b$ & $8.09 \mathrm{ab}$ & $33.17 \mathrm{a}$ \\
\hline \multirow{5}{*}{ middle water } & $50 \% \mathrm{IW}+\mathrm{WW}$ & $0.103 b$ & $1.90 \mathrm{~b}$ & $9.05 \mathrm{~b}$ & $0.12 b$ & $8.09 \mathrm{ab}$ & $29.17 b c$ \\
\hline & $25 \% \mathrm{IW}+\mathrm{WW}$ & $0.120 \mathrm{a}$ & $2.09 \mathrm{ab}$ & $9.21 \mathrm{~b}$ & $0.012 b$ & $7.98 b c$ & $28.43 c$ \\
\hline & WW & $0.123 \mathrm{a}$ & $2.34 \mathrm{a}$ & $12.42 \mathrm{a}$ & $0.13 a$ & $7.89 \mathrm{c}$ & $31.20 \mathrm{ab}$ \\
\hline & $\mathrm{CV}$ & 8.456 & 10.56 & 10.43 & 2.83 & 0.93 & 4.56 \\
\hline & $\operatorname{LSD}(0.05)$ & 0.017 & 0.38 & 1.06 & 0.01 & 0.14 & 2.5 \\
\hline \multirow{6}{*}{ Lower water } & IW & $0.097 \mathrm{~b}$ & $1.78 \mathrm{~b}$ & $8.34 \mathrm{~b}$ & 0.12 & $8.22 \mathrm{a}$ & $27.65 b$ \\
\hline & $75 \% \mathrm{IW}+\mathrm{WW}$ & $0.093 b$ & $2.02 \mathrm{ab}$ & $9.44 \mathrm{ab}$ & 0.12 & $8.12 \mathrm{c}$ & $27.73 b$ \\
\hline & $25 \% \mathrm{IW}+\mathrm{WW}$ & $0.137 \mathrm{a}$ & $1.99 \mathrm{ab}$ & $10.02 \mathrm{ab}$ & 0.12 & $7.95 \mathrm{~d}$ & $35.31 \mathrm{a}$ \\
\hline & WW & $0.130 \mathrm{a}$ & $2.12 \mathrm{a}$ & $11.37 \mathrm{a}$ & 0.12 & $7.91 \mathrm{e}$ & $33.73 \mathrm{a}$ \\
\hline & $\mathrm{CV}$ & 7.78 & 8.12 & 14.48 & 3.11 & 0.21 & 24.98 \\
\hline & $\operatorname{LSD}(0.05)$ & 0.016 & 0.3 & 1.94 & $\mathrm{~N}$ & 0.03 & 3.67 \\
\hline
\end{tabular}

Where IW, 75\%IW+WW, 50\% IW+WW, 25\%IW+WW and WW refer to soil sample taken from $100 \%$ ground water (irrigation water), $75 \%$ ground water $+25 \%$ Akaki River water, $50 \%$ ground water $+50 \%$ Akaki River water, $25 \%$ ground water $+75 \%$ Akaki River water and 100\% Akaki River water irrigated lettuce growing pot, respectively. Values are given as means of triplicates $\pm \mathrm{SD}$. The mean values in the same column having different superscript letters are significantly different from each other at 5\% confident interval.

Table 2. Mean concentration of $\mathrm{Cd}, \mathrm{Pb}, \mathrm{Fe}, \mathrm{Zn}, \mathrm{Cr}$ and $\mathrm{Cu}$ of soil samples after lettuce harvesting in acid digestion method ( $\mathrm{n}=3$ in $\mathrm{mg} / \mathrm{kg}$ ).

\begin{tabular}{|c|c|c|c|c|c|c|c|}
\hline & S. code & Cd & $\mathbf{P b}$ & $\mathbf{F e}$ & $\mathbf{Z n}$ & $\mathrm{Cr}$ & $\mathrm{Cu}$ \\
\hline \multirow{7}{*}{$\begin{array}{l}\text { Upper Akaki } \\
\text { water }\end{array}$} & IW & $0.47 \mathrm{c}$ & $8.00 \mathrm{~d}$ & $13557.30 \mathrm{~d}$ & $40.00 \mathrm{e}$ & $5.60 \mathrm{e}$ & $45.00 \mathrm{e}$ \\
\hline & $75 \% \mathrm{IW}+\mathrm{WW}$ & $3.08 \mathrm{~b}$ & $14.00 \mathrm{~d}$ & $14097.00 \mathrm{~cd}$ & $77.90 \mathrm{~d}$ & $21.60 d$ & $88.17 d$ \\
\hline & $50 \% \mathrm{IW}+\mathrm{WW}$ & $3.19 b$ & $36.00 \mathrm{c}$ & $14466.70 \mathrm{c}$ & $108.00 \mathrm{c}$ & $25.52 \mathrm{c}$ & $108.33 c$ \\
\hline & $25 \% \mathrm{IW}+\mathrm{WW}$ & $3.23 b$ & $101.60 \mathrm{~b}$ & $15060.00 \mathrm{~b}$ & $159.67 b$ & $30.48 b$ & $133.67 b$ \\
\hline & WW & $3.43 \mathrm{a}$ & $118.00 \mathrm{a}$ & $16800.00 \mathrm{a}$ & $224.67 \mathrm{a}$ & $39.36 \mathrm{a}$ & $149.88 \mathrm{a}$ \\
\hline & $\mathrm{CV}$ & 3.77 & 8.49 & 2.05 & 12.93 & 5.30 & 6.21 \\
\hline & $\operatorname{LSD}(0.05)$ & 0.19 & 8.88 & 570.75 & 22.72 & 2.45 & 12.28 \\
\hline \multirow{6}{*}{$\begin{array}{l}\text { Middle } \\
\text { Akaki water }\end{array}$} & $75 \% \mathrm{IW}+\mathrm{WW}$ & $2.62 d$ & $33.40 \mathrm{c}$ & $13898.00 \mathrm{c}$ & $97.67 d$ & $22.56 b$ & $55.00 \mathrm{~d}$ \\
\hline & $50 \% \mathrm{IW}+\mathrm{WW}$ & $2.84 \mathrm{c}$ & $42.50 \mathrm{~b}$ & $13921.30 \mathrm{c}$ & $141.33 \mathrm{c}$ & $24.00 \mathrm{~b}$ & $93.50 \mathrm{c}$ \\
\hline & $25 \% \mathrm{IW}+\mathrm{WW}$ & $3.05 b$ & $40.90 \mathrm{~b}$ & $14986.70 \mathrm{~b}$ & $160.67 b$ & $29.79 a$ & $112.33 b$ \\
\hline & WW & $3.22 \mathrm{a}$ & $49.30 \mathrm{a}$ & $15613.30 \mathrm{a}$ & $206.00 \mathrm{a}$ & $29.84 \mathrm{a}$ & $130.00 \mathrm{a}$ \\
\hline & $\mathrm{CV}$ & 2.25 & 5.15 & 1.34 & 3.93 & 5.15 & 9.29 \\
\hline & LSD (0.05) & 0.10 & 3.35 & 363.38 & 9.70 & 2.16 & 14.90 \\
\hline \multirow{9}{*}{$\begin{array}{l}\text { Lower Akaki } \\
\text { water }\end{array}$} & IW & $0.53 d$ & 8.00 & $13576.00 \mathrm{e}$ & $46.67 \mathrm{e}$ & $5.42 \mathrm{c}$ & $45.00 \mathrm{c}$ \\
\hline & $50 \% \mathrm{IW}+\mathrm{WW}$ & $2.81 \mathrm{~b}$ & $37.20 \mathrm{c}$ & $14886.70 \mathrm{c}$ & $122.67 \mathrm{c}$ & $16.00 \mathrm{~b}$ & $62.83 b$ \\
\hline & $25 \% \mathrm{IW}+\mathrm{WW}$ & $2.87 b$ & $44.60 \mathrm{~b}$ & $15753.30 \mathrm{~b}$ & $144.33 b$ & $20.00 \mathrm{~b}$ & $66.00 \mathrm{~b}$ \\
\hline & WW & $3.23 \mathrm{a}$ & $49.00 \mathrm{a}$ & $16240.00 \mathrm{a}$ & $201.67 \mathrm{a}$ & $29.52 \mathrm{a}$ & $143.50 \mathrm{a}$ \\
\hline & $\mathrm{CV}$ & 6.28 & 4.65 & 1.48 & 4.42 & 15.11 & 6.27 \\
\hline & $\operatorname{LSD}(0.05)$ & 0.28 & 2.69 & 414.30 & 10.02 & 4.54 & 8.76 \\
\hline & FAO/WHO [36] & 3 & 100 & 5000 & 300 & 50 & 100 \\
\hline & USEPA, [44] & 3 & 300 & - & 300 & 150 & 140 \\
\hline & $\mathrm{EU},[43]$ & 3 & 300 & - & 200 & - & 50 \\
\hline
\end{tabular}

\subsection{Levels of Heavy Metals in Soil Samples After Harvesting of Lettuce From Pot}

The concentrations of $\mathrm{Cd}, \mathrm{Pb}, \mathrm{Fe}, \mathrm{Zn}, \mathrm{Cr}$ and $\mathrm{Cu}$ in the digested samples of soil were determined by FAAS. The concentrations of these metals before planting were 0.61 , $8.12,13601.00,52.01,6.01$ and 54.12 in $\mathrm{mg} / \mathrm{kg}$ respectively and the concentration of the metal after harvesting are 
presented in Table 2 in all treatments the concentration of iron were much higher than other. As shown in Table 2, the recorded results of accumulated heavy metals in soil showed that iron, zinc and copper showed relatively higher values in the all five treatment (IW, $75 \% \mathrm{IW}+\mathrm{WW}, 50 \% \mathrm{IW}+\mathrm{WW}$, $25 \% \mathrm{IW}+\mathrm{WW}, \mathrm{WW}$ ) and three location upper, middle and lower Akaki river) compared to other heavy metals. Those directs wastewater might contain more sources of these metals. In generally, heavy metals like, Lead $(\mathrm{Pb})$, and cadmium $(\mathrm{Cd})$ have no beneficial effects in humans, and there is no known homeostasis mechanism for them [17]. They are generally considered the most toxic to humans and animals; the adverse human health effects associated with exposure to them, even at low concentrations, are diverse and include, but are not limited to, neurotoxic and carcinogenic. The metals considered in this study include the metals which are micro-nutrient such as iron, zinc, cobalt and copper and the non-essential/toxic heavy metal which are toxic to plant when present in the soil at concentrations above tolerance levels for the non-essential metals, $\mathrm{Cr}, \mathrm{Pb}$ and $\mathrm{Cd}$ are recognized as health hazardous and all have caused major health problems as a result of environmental pollution [17].

The means in the same column having different superscript letters are significantly different from each other at $5 \%$ confidence interval.

\subsubsection{Chromium in Soil Samples}

Chromium plays a vital role in the metabolism of cholesterol, fat, and glucose. Its deficiency causes hyperglycemia, elevated body fat, and decreased sperm count, while at high concentration it is toxic and carcinogenic [35]. As shown in Table 2 above, the $\mathrm{Cr}$ contents in the soil samples after pot trials were found to be within the range of 4.91 and $39.36 \mathrm{mg} / \mathrm{kg}$. The highest and lowest contents of $\mathrm{Cr}$ occurred in the upper Akaki river irrigated soil and irrigated water irrigated soil, respectively. Cr permissible level in farm field set by WHO/FAO [36] is $50 \mathrm{mg} / \mathrm{kg}$. But, the levels of $\mathrm{Cr}$ in detected soil samples from pot experiment might be safe for human health. But the increment of $\mathrm{Cr}$ concentration in Akaki river water irrigated pot soil samples were increase rapidly.

\subsubsection{Cadmium in Soil Samples}

Cadmium is also a non-essential heavy metal. It is extremely toxic even at low concentration. It causes learning disabilities and hyperactivity in children [37]. As shown in Table 2, the experimental results showed that $\mathrm{Cd}$ concentration in soil samples occurred in the range of 0.47 and $3.43 \mathrm{mg} / \mathrm{kg}$. The highest and lowest contents of $\mathrm{Cd}$ occurred in the upper Akaki river irrigated soil and irrigated water irrigated soil, respectively. WHO/FAO [36] permissible limit of cadmium in soil is $3 \mathrm{mg} / \mathrm{kg}$. So, the concentration of cadmium found in upper Akaki river $(75 \%$ IW+WW, 50\% IW+WW, 25\% IW+WW and WW), middle Akaki river $(25 \% \mathrm{IW}+\mathrm{WW}$ and $\mathrm{WW})$ and lower Akaki river (WW) irrigated soil were above the permissible limit set by $\mathrm{WHO} / \mathrm{FAO}[36]$ it might be harmful for human health.

\subsubsection{Zinc in Soil Samples}

The natural range of zinc in soils is $10-300 \mathrm{mg} / \mathrm{kg}$ [38]. It is the basic component of a large number of different enzymes and plays structural, regulatory, and catalytic functions. As shown in Table 2 above, the soil concentration of zinc in this study was within these natural ranges with values ranging between $40.00 \mathrm{mg} / \mathrm{kg}$ to $224.67 \mathrm{mg} / \mathrm{kg}$. $\mathrm{WHO} / \mathrm{FAO}$ permissible limit of zinc in soil is $300 \mathrm{mg} / \mathrm{kg}$. So, the concentration of zinc we obtained now is found to be below the permissible limit set by WHO/FAO [36] in all treatment irrigated soil samples.

\subsubsection{Iron in Soil Samples}

Iron is the most abundant and most essential constituent for all plants and animals. On the other hand, at high concentration, it causes tissues damage and some other diseases in humans. It is also responsible for anemia and neurodegenerative conditions in human being [39]. As shown in Table 2 above, the results indicate that soil samples contained $\mathrm{Fe}$ in the concentration range of 13557.30 and $16240.00 \mathrm{mg} / \mathrm{kg}$. $\mathrm{WHO} / \mathrm{FAO}$ [36] permissible limit of iron in soil is $5000 \mathrm{mg} / \mathrm{kg}$. So, the concentration of iron found in all soil samples from pot experiment might be harmful for human health, even though in irrigated water irrigated soil samples the concentration of $\mathrm{Fe}$ was above the permissible level.

\subsubsection{Lead in Soil Samples}

Lead is one of the more insistent metals and is predictable to have a soil retention time of 150 to 5000 years [40]. It is a non-essential HM. High level accumulation of $\mathrm{Pb}$ in body causes anemia, colic, headache, brain damage, and central nervous system disorder [41]. As shown in Table 2, the soil samples contained $\mathrm{Pb}$ concentrations in the range of 7.00 $118.00 \mathrm{mg} / \mathrm{kg}$. WHO/FAO [36] permissible limit of lead in soil is $100 \mathrm{mg} / \mathrm{kg}$ except $100 \%$ upper Akaki river water irrigated soil samples might be safe for human health. But the increment of $\mathrm{Pb}$ concentration in Akaki river water irrigated pot soil samples were increase rapidly.

\subsubsection{Copper in Soil Samples}

Being an essential trace element, it is necessary for many enzymes. High concentration of $\mathrm{Cu}$ causes metal fumes fever, hair and skin decolorations, dermatitis, respiratory tract diseases, and some other fatal diseases in human beings [42] As shown in Table 2 above, highest level $(149.88 \mathrm{mg} / \mathrm{kg})$ of $\mathrm{Cu}$ was found in $100 \%$ upper Akaki river water irrigated soil and the soil irrigated with irrigation water had the smallest level $(35.00 \mathrm{mg} / \mathrm{Kg})$ of $\mathrm{Cu}$. WHO/FAO [36] allowable limit of lead in soil is $100 \mathrm{mg} / \mathrm{kg}$. Also the concentration of copper in upper Akaki river $(50 \% \mathrm{IW}+\mathrm{WW}, 25 \% \mathrm{IW}+\mathrm{WW}$ and $\mathrm{WW}$ ), middle Akaki river (25\% IW+WW and WW) and lower Akaki river (WW) irrigated soil was above the concentration permissible limit set by EU [43]; USEPA [44] as shown in Table 2.

\subsection{Concentration of Metals in the Lettuce Samples}

The concentrations of $\mathrm{Cd}, \mathrm{Pb}, \mathrm{Fe}, \mathrm{Zn}, \mathrm{Cr}$ and $\mathrm{Cu}$ in lettuce plant collected from experimental pots are presented in Table 
3. From the study, the concertation of all metals in the detected sample were accumulated to greater or lesser extents.

Table 3. Mean concentration of $\mathrm{Cd}, \mathrm{Pb}, \mathrm{Fe}, \mathrm{Zn}$, $\mathrm{Cr}$ and $\mathrm{Cu}$ of lettuce samples in wet digestion method ( $\mathrm{n}=3 \mathrm{in} \mathrm{mg} / \mathrm{kg}$ ).

\begin{tabular}{|c|c|c|c|c|c|c|c|}
\hline & S. code & Cd & $\mathbf{P b}$ & $\mathbf{F e}$ & $\mathbf{Z n}$ & $\mathrm{Cr}$ & $\mathbf{C u}$ \\
\hline \multirow{7}{*}{ Upper Akaki water } & IW & $0.047 \mathrm{~d}$ & $0.51 d$ & $345.60 \mathrm{c}$ & $2.96 \mathrm{e}$ & $0.98 \mathrm{e}$ & $2.39 \mathrm{~d}$ \\
\hline & $75 \% \mathrm{IW}+\mathrm{WW}$ & $0.233 c$ & $0.78 \mathrm{~d}$ & $352.43 \mathrm{~cd}$ & $5.19 \mathrm{~d}$ & $4.32 \mathrm{~d}$ & $4.41 \mathrm{c}$ \\
\hline & $50 \% \mathrm{IW}+\mathrm{WW}$ & $0.223 b$ & $2.00 \mathrm{c}$ & $361.67 \mathrm{c}$ & $7.20 \mathrm{c}$ & $5.1 \mathrm{c}$ & $5.42 \mathrm{~b}$ \\
\hline & $25 \% \mathrm{IW}+\mathrm{WW}$ & $0.237 \mathrm{c}$ & $6.53 b$ & $384.75 b$ & $9.51 \mathrm{~b}$ & $5.66 \mathrm{~b}$ & $6.03 b$ \\
\hline & WW & $0.263 \mathrm{a}$ & $6.55 \mathrm{a}$ & $420.00 \mathrm{a}$ & $11.66 \mathrm{a}$ & $7.87 \mathrm{a}$ & $7.49 a$ \\
\hline & $\mathrm{CV}$ & 1.550 & 5.32 & 2.18 & 5.52 & 5.67 & 7.82 \\
\hline & $\operatorname{LSD}(0.05)$ & 0.010 & 0.31 & 15.32 & 0.76 & 0.51 & 0.76 \\
\hline \multirow{6}{*}{ Middle Akaki water } & $75 \% \mathrm{IW}+\mathrm{WW}$ & $0.200 \mathrm{c}$ & $1.94 \mathrm{c}$ & $348.03 b$ & $6.51 \mathrm{c}$ & $4.58 \mathrm{~b}$ & $3.09 \mathrm{~d}$ \\
\hline & $50 \% \mathrm{IW}+\mathrm{WW}$ & $0.230 \mathrm{~b}$ & $2.35 \mathrm{~b}$ & $350.12 b$ & $8.89 b$ & $4.80 \mathrm{~b}$ & $4.88 \mathrm{c}$ \\
\hline & $25 \% \mathrm{IW}+\mathrm{WW}$ & $0.230 \mathrm{~b}$ & $2.36 \mathrm{~b}$ & $384.67 \mathrm{a}$ & $8.97 b$ & $5.71 \mathrm{a}$ & $5.89 b$ \\
\hline & WW & $0.250 \mathrm{a}$ & $2.75 \mathrm{a}$ & $391.00 \mathrm{a}$ & $11.30 \mathrm{a}$ & $5.97 \mathrm{a}$ & $6.63 a$ \\
\hline & $\mathrm{CV}$ & 2.240 & 5.40 & 1.07 & 2.90 & 6.52 & 3.02 \\
\hline & $\operatorname{LSD}(0.05)$ & 0.010 & 0.20 & 7.34 & 0.42 & 0.54 & 0.25 \\
\hline \multirow{8}{*}{ Lower Akaki water } & IW & $0.043 \mathrm{~d}$ & $0.46 \mathrm{e}$ & $340.07 \mathrm{e}$ & $3.18 \mathrm{e}$ & $0.95 \mathrm{~d}$ & $2.32 \mathrm{c}$ \\
\hline & $25 \% \mathrm{IW}+\mathrm{WW}$ & $0.230 \mathrm{~b}$ & $2.48 \mathrm{~b}$ & $394.50 \mathrm{~b}$ & $9.54 b$ & $4.00 \mathrm{~b}$ & $3.30 \mathrm{~b}$ \\
\hline & WW & $0.250 \mathrm{a}$ & $2.72 \mathrm{a}$ & $406.00 \mathrm{a}$ & $13.44 \mathrm{a}$ & $5.77 \mathrm{a}$ & $7.18 \mathrm{a}$ \\
\hline & $\mathrm{CV}$ & 2.87 & 4.11 & 1.42 & 4.83 & 13.55 & 5.67 \\
\hline & LSD (0.05) & 0.01 & 2.31 & 9.99 & 0.73 & 0.80 & 0.40 \\
\hline & WHO [45] & 0.20 & 0.5 & 150 & 1.5 & 1.20 & 2.0 \\
\hline & $\mathrm{CMH}[48]$ & $0.05-0.2$ & $0.1-0.3$ & - & - & $0.5-1.0$ & \\
\hline & FAO [49] & 0.01 & 5.00 & - & 2.00 & - & 0.2 \\
\hline
\end{tabular}

The means in the same column having different superscript letters are significantly different from each other at $5 \%$ confidence interval.

\subsubsection{Cadmium in Lettuce}

$\mathrm{Cd}$ concentration in lettuce samples collated for pot experiment were ranged of $0.043-0.263 \mathrm{mg} / \mathrm{kg}$ in all three part of the river water irrigated lettuce samples as shown in Table 3. The concentration of $\mathrm{Cd}$ was maximum $(0.263$ $\mathrm{mg} / \mathrm{kg}$ ) in lettuce sample irrigated with $100 \%$ upper Akaki river water, this, result was higher than permissibility level set by WHO [45]. Cadmium is more solvable as compared to other metals so, it can accumulate more into the vegetables tissues [46]. The permissible limits of $\mathrm{Cd}$ is $(0.20 \mathrm{mg} / \mathrm{Kg})$ in the plant tissue proposed by WHO [45].

\subsubsection{Lead in Lettuce}

Results show that the levels of lead in the lettuce studied had a range of 0.42 to $6.55 \mathrm{mg} / \mathrm{kg}$ as shown in Table 3. A similar study that is conducted by Girmaye [47] reported that lead concentrations of lettuce ranged from $2.3-5.30 \mathrm{mg} / \mathrm{kg}$ sample by which super passed the maximum permissible level of $\mathrm{Pb}$ set by WHO [45]; $\mathrm{CMH}$ [48]; FAO [49]. In this study, the high level of $\mathrm{Pb}$ in lettuce suggests that the Akaki river water used for irrigation was not good for irrigation of crops in general and leafy vegetables in particular.

\subsubsection{Iron in Lettuce}

In this study, Fe concentration from the lettuce samples for pot trials varied between 339.83-420.00 mg/kg The concentration of $\mathrm{Fe}$ was maximum $(420.00 \mathrm{mg} / \mathrm{kg})$ in lettuce sample irrigated with $100 \%$ middle Akaki river water, this, result was higher than permissibility level set by WHO [45] and WHO [45] permissible limit is $150 \mathrm{mg} / \mathrm{kg}$ (Table 3). Fe is vital element for all plants has many significant biological roles in the processes as diverse as photosynthesis, chloroplast development and chlorophyll biosynthesis [50]. In humans, increased body stores of iron have been shown to increase the risk of several estrogen-induced cancers [51].

\subsubsection{Zinc in Lettuce}

In this study, results show that the levels of zinc in lettuce had a range of $2.96-11.66 \mathrm{mg} / \mathrm{kg}$, middle Akaki river water irrigated lettuce $3.15-11.30 \mathrm{mg} / \mathrm{kg}$ and lower Akaki River irrigated lettuce $3.18-13.44 \mathrm{mg} / \mathrm{kg}$ and WHO [45] permissible limit is $1.50 \mathrm{mg} / \mathrm{kg}$ (Table 3). All the ventures exhibited very high concentration compared to the permissible limit set by WHO [45]; CMH [48]; FAO [49]. The concentration may be as a result of the number of factories wastewater immerging in to Akaki River.

\subsubsection{Chromium in Lettuce}

In this study the chromium contents in lettuce samples collected from pots experiment irrigated with Akaki river water were obtained to have ranged in Upper Akaki water irrigated lettuce $0.97 \pm 0-7.87 \mathrm{mg} / \mathrm{kg}$, middle Akaki river water irrigated lettuce $0.97-5.97 \mathrm{mg} / \mathrm{kg}$ and lower Akaki river irrigated lettuce $0.95-5.77 \mathrm{mg} / \mathrm{kg}$ these, result were higher than permissibility level set by WHO [45] except the irrigation water irrigated lettuce sample in all three part of the river Table 3.

\subsubsection{Copper in Lettuce}

In this study, $\mathrm{Cu}$ concentration from the lettuce samples from pot experiments varied between $1.68-7.49 \mathrm{mg} / \mathrm{kg}$ and WHO [45] permissible limit is $2.0 \mathrm{mg} / \mathrm{kg}$ (Table 3). High levels of Copper 
present in the parts of the plants may be due to the absorption ability of the plants to get the trace heavy metals from the polluted soils. $\mathrm{Cu}$ is especially important in seed production, disease resistance, and regulation of water [17].

\subsection{Level of Heavy Metals in Akaki River Water Samples}

The distribution of heavy metals ( $\mathrm{Fe}, \mathrm{Zn}, \mathrm{Cu}, \mathrm{Cd}, \mathrm{Pb}$ and $\mathrm{Cr}$ ) in Akaki river water has been evaluated. Akaki river samples were collected from the upper, middle and lower part of Akaki River and taken to the laboratory for chemical analysis. As shown in Table 4, the result heavy metals in the Akaki river water samples were found to be in the order of $\mathrm{Zn}>\mathrm{Cu}>\mathrm{Fe}>\mathrm{Cr}>\mathrm{Pb}>\mathrm{Cd}$ in the three part of the river. Moreover the concentration of each heavy metal was higher than the permissible limit set by WHO [52] which could pose a huge threat to human health and the natural environment.

Table 4. Mean concentration of $\mathrm{Fe}, \mathrm{Zn}, \mathrm{Cu}, \mathrm{Cd}, \mathrm{Pb}$ and $\mathrm{Cr}$ in $\mathrm{mg} / \mathrm{L}$ of Akaki river sample $(n=3)$.

\begin{tabular}{|c|c|c|c|c|c|c|}
\hline S. code & $\mathrm{Fe}$ & Zn & $\mathbf{C u}$ & Cd & $\mathrm{Pb}$ & $\mathrm{Cr}$ \\
\hline ground water & $0.080 \mathrm{c}$ & $0.67 \mathrm{~d}$ & $0.63 c$ & $0.004 d$ & $0.017 \mathrm{~d}$ & $0.07 \mathrm{c}$ \\
\hline Upper Akaki & $0.28 \mathrm{a}$ & $2.67 \mathrm{a}$ & $1.40 \mathrm{a}$ & $0.087 \mathrm{a}$ & $0.080 \mathrm{a}$ & $0.14 \mathrm{a}$ \\
\hline Middle Akaki & $0.24 \mathrm{a}$ & $1.80 \mathrm{~b}$ & $1.10 \mathrm{~b}$ & $0.060 \mathrm{~b}$ & $0.053 b$ & $0.11 b$ \\
\hline Lower Akaki & $0.18 b$ & $1.4 \mathrm{c}$ & $0.97 b$ & $0.037 \mathrm{c}$ & $0.037 \mathrm{c}$ & $0.10 \mathrm{~b}$ \\
\hline $\mathrm{CV}$ & 9.79 & 11.32 & 11.15 & 6.950 & 7.890 & 7.33 \\
\hline LSD 0.05 & 0.04 & 0.37 & 0.23 & 0.007 & 0.007 & 0.02 \\
\hline WHO [52] & 0.30 & 0.03 & 0.01 & 0.003 & 0.050 & 0.10 \\
\hline
\end{tabular}

The mean values in the same column having different superscript letters are significantly different from each other at $5 \%$ confidence interval.

\subsubsection{Iron Akaki River Water}

Concentrations of iron in the Akaki river samples at upper, middle and lower part of the river were $0.28,0.24$ and 0.18 $\mathrm{mg} / \mathrm{L}$, respectively. Iron concentrations in three samples were above the recommended maximum concentration for irrigation [52] Table 4. The high concentration of iron in irrigation water contributes to soil acidification and loss of availability of phosphorus and molybdenum when applied to the soil [53].

\subsubsection{Zinc Akaki River Water}

Zinc concentration in Akaki river samples at upper, middle and lower part of the river were $2.67,1.80$ and $1.4 \mathrm{mg} / \mathrm{L}$, respectively. The samples exceeded the recommended maximum concentration for crop irrigation WHO, [52]. Zinc is the least toxic element in the human diet it is required to maintain the proper functioning of the immune system, normal brain activity and is essential in the growth and development of the foetus, but a very high concentration of zinc is very toxic, hence injurious to the human body [54].

\subsubsection{Copper Akaki River Water}

As shown in Table 4, Cu levels in Akaki River samples at the upper, middle and lower part of the river were 1.40, 1.10 and $0.97 \mathrm{mg} / \mathrm{L}$, respectively. These values were found to be higher than optional limit of $\mathrm{Cu}$ for irrigation water set by WHO [52] (Table 4).

\subsubsection{Cadmium Akaki River Water}

The results show that the Cd concentrations in the Akaki river samples at upper, middle and lower part of the river were $0.087,0.060,0.037 \mathrm{mg} / \mathrm{L}, \quad$ respectively. The concentrations of $\mathrm{Cd}$ obtained in the present study are above the permissible limit set by WHO [52] USEPA [44] for crop irrigation. Cadmium is considered to be hazardous metal because of its toxicity and accumulation capacity in the living system [4].

\subsubsection{Lead Akaki River Water}

Lead concentration in Akaki River samples at upper, middle and lower part of the river were $0.080,0.053$ and $0.037 \mathrm{mg} / \mathrm{L}$, respectively. The lead value were of to be higher than recommended limit of $\mathrm{Pb}$ for irrigation water set by WHO [52] and USEPA [44] (Table 4). This makes the water unsuitable for human consumption as $\mathrm{Pb}$ is known to be toxic even at low levels with resultant ill-health effects as chronic exposure has been linked to growth retardation in children [55]

\subsubsection{Chromium Akaki River Water}

The levels of $\mathrm{Cr}$ in the Akaki river samples at the upper, middle and lower part of the river were $0.14,0.11$ and 0.10 $\mathrm{mg} / \mathrm{L}$, respectively. These values are above the permissible limit set by WHO [52] and USEPA [52] (Table 4) for crop irrigation. $\mathrm{Cr}$ is a toxic element due to its harmful effect on human health, mainly in its hexavalent form [53].

\section{Conclusion}

As stated previously, the major aim of this study was to find out solution for heavy metal toxicity levels of Akaki River water for irrigation purpose. The Akaki River water, lettuce growing soil and lettuce samples that were growing with upper, middle and lower part of Akaki River water with ground water by the combination of control, 25, 50, 75, and $100 \%$ Akaki river water with ground water combination set as treatment) were subjected to wet-digestion and the concentration of detected metals were determined via FAAS. The level of heavy metals in upper, middle and lower from part of Akaki river water is above the recommended level set by WHO and USEPA for irrigation water. The concentration heavy metals in all diluted and undiluted upper, middle and lower Akaki River water irrigated lettuce samples were above the recommended levels set by WHO. But the concentration heavy metals in soil samples that lettuce were grown is within the recommended levels set by FAO/WHO, USEPA 
and $\mathrm{EU}$ in the other hand the levels of Fe was above the recommended levels set by the above organization. Based on facts obtained from this study we suggests that this formulation used for drip irrigation. And concerned official body (ies) to take the necessary precaution measures for cleaning the polluted Akaki River water.

\section{References}

[1] Akguc, N., Ozyigit, I. I. and Yarci, C. 2008. Pyracantha coccinea Roem. (Rosaceae) as a biomonitor for $\mathrm{Cd}, \mathrm{Pb}$ and $\mathrm{Zn}$ in Mugla province (Turkey). Pakistan Journal of Botany, 40 (4): 1767-1776.

[2] Hussain, I., L. Raschid, M. A. Hanjra, F. Marikar and W. Van der Hoek. 2001. A framework for analyzing socioeconomic, health and environmental impacts of wastewater use inagriculture in developing countries. Working Paper 26. Colombo: International Water Management Institute (IWMI).

[3] Scott, C., N. I. Faruqui and L. Raschid-Sally. 2004. Wastewater Use in Irrigated Agriculture: Management Challenges in Developing countries. In: Wastewater use in Irrigated agriculture: Confronting the livelihood and environmental realities. (Ed.): C. A. Scott. Ottawa, Canada: CAB International, International Water Management Institute, and International Development Research Centre.

[4] Hamilton, A. J., F. Stagnitti, X. Xiong, S. L. Kreidl, K. K. Benke and P. Maher. 2007. Reviews and Analyses Wastewater Irrigation: The State of Play. Vadose Zone J., 6: 823-840.

[5] Liu, W. H., J. Z. Zhao, Z. Y. Ouyang, L. Solderland and G. H. Liu. 2005. Impacts of sewage irrigation on heavy metal distribution and contamination in Beijing, China. Enviro. Int., 32: 805-812.

[6] Singh, K. P., D. Mohan, S. Sinha and R. Dalwani. 2004. Impact assessment of treated/ untreated wastewater toxicants discharged by sewage treatment plants on health, agricultural, and environmental quality in the wastewater disposal area. Chemosphere, 55: 227-255.

[7] Chen, Y., C. Wang and Z. Wang. 2005. Residues and source identification of persistentorganic pollutants in farmland soils irrigated by effluents from biological treatment plants. Environ. Int., 31: 778-783.

[8] Baker, A. J. M., R. D. Reeves and S. P. McGrath. 1991. In Situ Decontamination of Heavy Metal Polluted Soils Using Crops of Metal-Accumulating Plants- A Feasibility Study. In: (Eds.): R. E. Hinchee and R. F. Olfenbuttel. In Situ Bioreclamation. Butterworth-einemann Publishers, Stoneham, MA. 539-544.

[9] Alexander, P. D., B. J. Alloway and A. M. Dourado. 2006. Genotypic variations in the accumulation of $\mathrm{Cd}, \mathrm{Cu}, \mathrm{Pb}$ and $\mathrm{Zn}$ exhibited by six commonly grown vegetables. Environ. Pollut., 144 (3): 736-745.

[10] Shah, Z. and Riazullah. 2003. Evaluation of farm waste for heavy metals. Pak. J. Soil Sci., 22: 42-50.

[11] Cui, Y. J., Y. G. Zhu, R. Zhai, Y. Huang, Y. Qiu and J. Liang. 2005. Exposure to metal mixtures and human health impacts in a contaminated area in Nanning, China. Environ. Int., 31: 784-790.
[12] Bi, X., X. Feng, Y. Yang, G. Qiu, G. Li, F. Li, T. Liu, Z. Fu and Z. Jin. 2006. Environmental contamination of heavy metals from zinc smelting areas in Hezhang County, Western Guizhou, China. Environ. Int., 32: 883-890.

[13] Demlie M, Wohnlich S (2006) Soil and groundwater pollution of an urban catchment by trace metals: case study of the Addis Ababa region, central Ethiopia. Environ Geol 51: 421-431.

[14] Alemayehu T (2006) Heavy metal concentration in the urban environment of Addis Ababa, Ethiopia. Soil Sediment Contam 15: 591-602.

[15] Gizaw E, Legesse W, Haddis A, Deboch B, Birke W (2004) Assessment of factors contributing to eutrophication of Aba Samuel Water reservoir in Addis Ababa, Ethiopia. Ethiop J Health Sci 14: 112-223.

[16] Melaku S, Wondimu T, Dams R, Moens L (2007) Pollution status of Tinishu Akaki River and its tributaries (Ethiopia) evaluated using physico-chemical parameters, major ions, and nutrients. Bull Chem Soc Ethiop 21: 13-22.

[17] Bahiru B. D., Teju E., Kebede T., Demissie N. 2019. Levels of some toxic heavy metals $(\mathrm{Cr}, \mathrm{Cd}$ and $\mathrm{Pb})$ in selected vegetables and soil around eastern industry zone, central. African Journal of Agricultural Research Journal of Natural Sciences 14 (2): 92-101.

[18] APHA (American Public Health Association). 1999. American water works association, Water environment federation. Standard methods of the examination of water and wastewater, 20thed. New York: American Public Health Association, APHA, AWWA, and WPCF.

[19] Birtukan Aga and Gebregziabher Brhane. 2014. Determination the level of some heavy metals $(\mathrm{Mn}$ and $\mathrm{Cu}$ ) in drinking water using wet digestion method of Adigrat Town. International Journal of Technology Enhancements and Emerging Engineering Research, 2 (10): 32-36.

[20] Street, R. A. 2008. Heavy metals in South African medicinal plants research center for plant growth and development, $\mathrm{PhD}$ Dissertation, University of KwaZulu-Natal, Pietermaritzburg, South African.

[21] Loon, J. C., 1985. Selected methods of trace metal analysis biological and environmental samples. New York. 5: 3685-3689.

[22] Van Reeuwijk, L. P. 1992. Procedures for soil analysis, 3rd Ed. International Soil Reference and Information Center (ISRIC), Wageningen, the Netherlands. 34p.

[23] Richards, L. A. (ed.), U.S. Salinity Laboratory Staff (1954, Reprint 1969) Diagnosis and improvement of saline and alkaline soils. USDA Agriculture Handbook No. 60. U.S. Dept.

[24] Walkey, A. and Black, I. A. 1934. An examination of degtjareff method for determining soil organic matter and a proposed modification of the chromic acid titration method. Soil Science, 37: 29-38.

[25] Black, C. A. 1965. Methods of soil analysis. Part I, American Society of Agronomy.

[26] Olsen, S. R., Cole, C. V., Watanable F. S. and Dean L. A. 1954. Estimation of available phosphorus in soil by extraction with sodium bicarbonate. USDA Circular. 939: 1-19.

[27] Jackson, M. L. 1967. Chemical Analysis. Prentice Hall, Inc., Engle Wood Cliffs. New Jersey. 183-204. 
[28] Gomez and Gomez, 1984. Statistical procedures for agricultural researcher, 2 nd edition.

[29] Sharma, R. Kumar, M. Agrawal and F. Marshall, 2007. Heavy metal contamination of soil and vegetables in sub urban areas of Varanasi, India. Elsevier inc. 6: 357-362.

[30] Mulugeta Edeto, 2014. Determination of levels of some essential and nonessential metals in municipal water supply of west Shoa zone, Ambo town, Ethiopia. MSc. Graduate thesis, Haramaya University, Haramaya, Ethiopia.

[31] Prasad, R. 1992, Effect of liming on yield of soybean and nutrient availability in acidic soil. J. Indian Soc. Soil Sci. 40: 377-379.

[32] Landon, J. R., 1991. Booker Tropical Soil Manual: a handbook for soil survey and agricultural land evaluation in the tropics and subtropics. John Wiley \& Sons Inc., New York.

[33] Evans, L. J. 1989. Chemistry of metal retention by soils. Environmental Science and Technology, 23, 1046-1056.

[34] Afshin, K and Farid, D. 2007. Statistical analysis of accumulation and sources of heavy metals Occurrence in agricultural soil of Khoshk River banks, Shiraz Iran. AmericaEurasian Journal of Agriculture and Environment, 5: 565-573.

[35] Chishti, K. A., Khan, F. A., Hassan, S. S. M. 2011. Estimation of heavy metals in the seeds of blue and white capitalism's of silybum marianum grown in various districts of Pakistan. Journal of Basic and Applied Science, 7 (1): 45-49.

[36] FAO/WHO. 2001. Food additives and contaminants. Joint codex alimentarius commission, FAO/WHO Food standards Program. 34: 745-50.

[37] Hunt, J. R., 2003. Bioavailability of iron, zinc, and other trace minerals from vegetarian diets. American Journal of Clinical Nutrition, 78 (3): 6335-6395.

[38] Eddy, N. O., Odoemelem, S. A. and Mbaba, A. 2006. Elemental composition of soil in some dumpsites. Journal of Environmental Agricultural Food Chemistry, 5: 1349-1365.

[39] Fuortes, L. and. Schenck, D. 2000. Marked elevation of urinary zinc levels and pleuralfriction rub in metal fume fever. Veterinary and Human Toxicology, 42 (3): 164-165.

[40] Sobolev, D. and Begonia, M. F. T. 2008. Effects of Heavy metal contamination upon soil microbes: lead-induced changes in general and denitrifying microbial communities as evidenced by molecular markers. International Journal of Environmental Research in Public Health, 5 (5): 451-459.

[41] Rehman, A., Ullah, H., Khan, R. U. and Ahmad, I. 2013. Population based study of heavy metals in medicinal plant Capparis decidua. International Journal of Pharmacy and Pharmaceutical Sciences, 5 (1): 108-113.

[42] Khan, S., Cao, Q., Zheng, Y. M., Huang, Y. Z. and Zhu, Y. G.
2008. Health risk of heavy metals in contaminated soils and food crops irrigated with waste water in Beijing, China. Environmental Pollution Series, 152 (3): 686-692.

[43] European Union EU 2002. Heavy Metals in Wastes, European Commission on Environment (http://ec.europa.eu/environment/waste/studies/pdf/heavy_met alsreport.

[44] USEPA (United State Environmental Protection Agency). 2010. Risk-based concentration table. United State Environmental Protection Agency, Washington, DC, USA.

[45] WHO. 1999. Permissible limits of heavy metals in soil and plants (Geneva: World Health Organization), Switzerland.

[46] Farid H,, Izadi Z., Ismail I. F. and Alipour F. 2015. Relationship between quality of work life and organizational commitment among lecturers in a Malaysian public research university The Social Science Journal 25: 54-61.

[47] Girmaye Benti Regassa. 2012. Heavy metal and microbial contaminants of some vegetables irrigated with wastewater in selected farms around Adama town, Ethiopia. MSc. Graduate project, Haramaya University, Haramaya, Ethiopia.

[48] Chinese Ministry of Health (CMH). 2005. Maximum levels of contaminants in foods. $\mathrm{CMH}$, Beijing, China.

[49] FAO. 1985. Water Quality for Agriculture. Irrigation and drainage paper No. 29, Rev. 1. Food and agriculture organization of the United Nations, Rome.

[50] Marschner, H. 1995. Mineral nutrition of higher plants, 2nd edition. Academic Press, Toronto.

[51] Liehr, J. G. and Jones, J. S. 2001. Role of iron in estrogeninduced cancer. Current Medicinal Chemistry, 8: 839-849.

[52] WHO. 2006. WHO Guidelines for the Safe use of wastewater, excreta and greywater. Vol. I: Policy and Regulatory Aspects. Vol. II: Wastewater Use in Agriculture. Vol. III: wastewater and excreta use in aquaculture. Vol. IV: excreta and greywater use in agriculture. Geneva: World Health.

[53] Abagale, F. K., Sarpong, D. A., Ojediran, J. O., OseiAgyemang, R., Shaibu, A. G. and Birteeb, P. T. 2013. Heavy metal concentration in wastewater from car washing bays used for agriculture in the Tamale Metropolis, Ghana. International Journal of Current Research, 5 (06): 1571-1576.

[54] Helen, L. E., and Othman, O. C. 2014. Levels of selected heavy metals in soil, tomatoes and selected vegetables from Lushoto district-Tanzania. International Journal of Environmental Monitoring and Analysis, 2 (6): 313-319.

[55] Muiruri, M. J. 2009. Determination of concentration of selected heavy metals in Tilapia fish, sediments and water from Mbagathi and Ruiru Athi river tributaries, Kenya. MSc thesis, Kenyatta University, Kenya. 